\title{
Impactos do novo marco legal brasileiro na gestão da educação municipal
}

EDSON FRANCISCO DE ANDRADE*

\section{RESUMO}

$\mathrm{O}$ artigo discute os impactos do novo marco legal brasileiro no que concerne à mudança do paradigma de gestão da educação municipal. Inicialmente, rememoramos os avanços e a perplexidade quanto ao movimento de reinstituiçáo da democracia no Brasil. $\mathrm{Na}$ sequência, discutimos o advento do novo marco legal e seus impactos na gestáo da educaçáo municipal, sobretudo o significado da criaçáo do sistema de ensino no âmbito do poder local. Por fim, destacamos a necessidade de contrapartidas dos municípios quanto ao planejamento de suas políticas educacionais, em face das novas responsabilidades legais.

Palavras-chave: Administração da educaçáo, Ensino municipal, Políticas educacionais.

\section{RESUMEN}

El artículo discute los impactos del nuevo marco legal brasileño en lo que se refiere a los cambios del paradigma de gestión de la educación municipal. Inicialmente, recordamos los avances y la perplejidad en relación al movimiento de restitución de la democracia en Brasil. A continuación, discutimos el advenimiento del nuevo marco legal y sus impactos en la gestión de la educación municipal, en especial el significado de la creación del sistema de enseñanza en el ámbito del

* Professor da Universidade de Pernambuco - Campus Garanhuns, vinculado ao Núcleo de Estudos e Pesquisas em Políticas Públicas para a Educação: avaliação, planejamento e gestão educacional (edsonprofessor@uol.com.br). 
poder local. Por último, destacamos la necesidad de contrapartidas de los municipios para la planificación de sus políticas educativas, frente a las nuevas responsabilidades legales.

Palabras clave: Administración de la educación, Enseñanza municipal, políticas educativas.

\section{ABSTRACT}

This article discusses the impacts of Brazil's new law regarding the change of the management paradigm of municipal education. Initially, we recall the progress and perplexity resulting from the movement of re-establishing democracy in Brazil. Next, we discuss the advent of the new legal framework and its impact on the management of municipal education, especially the significance of the creation of a local education system. Finally, we stress the necessity for municipalities to play their role regarding the planning of their educational policies in light of their new legal responsibilities.

Keywords: Education management, Municipal teaching system, Educational policies. 


\section{VINTE ANOS DA CONSTITUIÇÃO FEDERATIVA DO BRASIL: AVANÇOS E PERPLEXIDADES}

Após longos anos em que o regime militar impunha irrestrita centralização do poder, uma nova página da história democrática brasileira começou a ser escrita, advento que marcara os anos 1980 por meio dos diversos movimentos literários e político-sociais, que pretendiam trazer à luz a efervescência dos segmentos da sociedade civil que reclamavam maior participação na vida política do país. É imperativo reconhecermos que o objetivo da ditadura militar de cercear os espaços de atuação da sociedade civil, reprimindo duramente qualquer tipo de mobilização dos cidadáos no sentido de contrapor a ordem imposta pelos generais-presidentes, instigou, na realidade, a organização de uma sociedade muito mais determinada para a intervenção nos espaços públicos do que aquela que foi rendida pelo golpe de 1964 . Como observa Coutinho (1992, p. 48),

o Brasil emergiu do longo período ditatorial iniciado em 1964 com uma sociedade civil complexa e articulada. Malgrado todas as tentativas (muitas vezes exitosas) de reprimir e/ou neutralizar essa sociedade civil, a ditadura militar não foi capaz de inverter uma tendência que se configurou como dominante, pelo menos desde os anos 1930, refiro-me à tendência de "ocidentalização" de nossa sociedade, ou seja, à continuação de uma relação equilibrada entre Estado e sociedade civil, que supera a antiga situação "oriental" onde o Estado era tudo e a sociedade civil é primitiva e gelatinosa.

O interesse pela ampla e definitiva intervenção na máquina estatal parecia estar impregnado nos ideais dos sindicatos, das associações, das organizaçóes partidárias, bem como dos profissionais ligados às mais diversas instituiçôes sociais. Com efeito, toda essa crescente mobilização social refletia a urgência pela reconstrução das instituiçóes democráticas, drasticamente sufocadas pelo golpe militar de 1964.

No contexto dos grandes movimentos da década de 1980, merecem ênfase particular: a congruência de forças políticas para a reinstituição do regime político democrático - tornando-se emblemática pelo movimento das Diretas Já, assim como a formulação e reformulação de leis de abrangência nacional ${ }^{1}$. As atençóes estavam fortemente voltadas para a reestruturação do marco legal, tendo como justificativa, para tanto, a necessidade de uma nova Constituiçáo Federal que fundasse os prin-

${ }^{1}$ A promulgação da Constituição Federal de 1988 constitui parte significativa do construto das condiçōes objetivas para o exercício dos princípios democráticos. 
cípios democráticos, concernentes à realidade histórica brasileira contemporânea, assim como leis específicas de validade nacional, focando as nuances conjunturais de setores como Educaçáo, Defesa Social, Meio Ambiente, entre outras.

Destaca-se, nesse contexto, uma maior articulação dos trabalhadores que, em detrimento da repressáo militar, começaram paulatinamente a articular suas forças, fato que explica as consideraçóes de Coutinho (1992) quando afirma que emergimos da ditadura como uma sociedade do tipo ocidental. Ou seja, uma sociedade civil que passa a lutar por uma relaçáo equilibrada com o Estado. Interessa-nos, sobremaneira, a postura que essa sociedade articulada e plural emergida dos anos de centralização do poder irá desenvolver na grande tarefa de redemocratização do Brasil. "Atores sociais e intérpretes, no próprio calor da hora, se aperceberam que havia algo de novo emergindo na história social do país, cujo significado, no entanto, era difícil de ser imediatamente captado" (Sader, 1988, p. 26).

Fica evidente, nessa conjuntura, que o anseio pela redemocratização não se restringe ao movimento de reinstituiçáo do parlamento como representação do desejo da maioria. Na realidade, o grande desafio é fortalecer a democracia em seu principal locus - a sociedade (nas suas diversas formas de organizaçáo). A mobilizaçáo civil para a criação de novas instâncias de participaçáo demonstra o reconhecimento de que o processo de democratização implica a ação colegiada, tendo em vista a defesa do bem comum por meio da intervenção nos espaços públicos. O propósito era justamente construir as bases para uma sociedade forte, capaz de interferir nas decisōes estatais.

O ideário de atuação dos movimentos sociais que emerge dos anos 1980 pressupóe a participaçáo dos sujeitos no espaço público como interlocutores entre o Estado e a sociedade civil. Isso significa que o grande desafio a ser superado náo se trata de assumir as responsabilidades do Estado, mas, sobretudo, de participar do processo de construção de normas e procedimentos que vão nortear o jogo democrático, do qual todos os sujeitos sociais demonstravam estar sequiosos por participação.

\section{OS PRINCÍPIOS DEMOCRÁTICOS NA GESTÃO PÚBLICA NO CONTEXTO DOS ANOS 1990}

Conforme enfatizamos, as décadas de 1970 e 1980 marcaram a história recente do Brasil pelas lutas em favor do fortalecimento dos organismos da sociedade civil no sentido de ampliar o cânone democrático para além da instituiçáo do parlamento. Tratava-se de colocar em evidência a qualidade de atuação de sujeitos dispostos a participar do planejamento e intervir nas decisóes, constituindo uma relação que 
expressava, substantivamente, o ideário de descentralização no que diz respeito à capacidade de interferir politicamente nas instâncias deliberativas do Estado.

Mesmo reconhecendo a importância dos fatos ocorridos durante os governos de Fernando Collor de Mello e, logo depois, de Itamar Franco, evidenciaremos o período dos governos Fernando Henrique Cardoso, em face de esse ter sido um governo que claramente expôs um modelo de ação estatal bastante divergente daquele que ganhara força nos anos 1980.

No que concerne ao nosso interesse de estudo, chamamos a atenção para o fato que, durante os anos 1990, o discurso da democratização na gestáo é perpassado por expressóes que buscam revelar a urgência de se instaurar critérios de excelência, de eficácia e eficiência, de competitividade e de outros aspectos do campo da racionalidade econômica.

Quando estávamos tratando da relação entre a sociedade civil e o Estado, ressaltando as contribuiçóes populares da década anterior, falávamos da possibilidade de sepultar o Estado do tipo monolítico que a ditadura defendia e aderir a uma outra lógica de açáo estatal. Assim, estávamos dizendo, consequentemente, que "náo se trata de um Estado qualquer, mas de um Estado democrático" (Casassus, 1995, p. 52). Faz-se, então, necessário esclarecer que a dinâmica de avaliação educacional do período dos governos Fernando Henrique Cardoso exige que façamos as devidas consideraçóes sobre o tipo de Estado que pretendia se firmar naquela conjuntura histórica. Na realidade,

trata-se de um Estado altamente intervencionista: legislador, julgador, controlador da pauta da mídia e que pressiona, através de meios questionáveis, parlamentares e meios de comunicaçáo (...) Estado interventor: que deixa todos os preços serem regulados pelo mercado, menos o preço da força de trabalho: o salário mínimo é rigidamente controlado pelo governo. Estado que intervém para reprimir movimentos de trabalhadores; para mudar a constituição, para suprimir ou reduzir direitos trabalhistas - flexibilizaçăo da CLT (...). Em suma, para cumprir seu objetivo central - colocar a economia do país a serviço do capital nacional e internacional - o Estado intervém pesadamente. (Lesbaupin; Mineiro, 2002, p. 74-75)

Percebe-se que os fatos revelam que o governo Fernando Henrique Cardoso inaugura uma nova relaçáo com a sociedade civil. O Estado dos anos 1990 pretendia ser muito, mas para isso náo poderia ser tudo. Nesse cenário os personagens que haviam entrado em cena na década anterior passam a ocupar outro papel. $O$ interessante é que sua participação constitui peça fundamental dentro do projeto estatal. 
Para o cumprimento dessa perspectiva, o governo apresenta uma nova lógica de açáo, como observa Azevedo (2002), na qual transfere parte substancial de suas responsabilidades aos níveis de administração municipal e estadual, garantindo por meio de programas federais o repasse de recursos financeiros direto às escolas, assumindo, assim, o modelo gerencial de administração das instituiçóes públicas, em justificativa de que o problema não é de escassez de recursos e sim de administraçáo.

Fica evidente, nessa nova agenda estatal, que a concepção de participação da sociedade civil não é mais aquela que pressupóe a intervençáo na proposição das políticas, mas sim a de provedora de serviços. Na realidade, "o Estado delegou parte das suas responsabilidades sociais ao terceiro setor, descentralizando a gestáo, mas centralizando a decisão política. Em alguns casos, a relaçáo construída com as instituiçóes públicas é tão forte que atingiu um nível de dependência que as torna mais parte do Estado do que da sociedade civil" (Lima, 2004, p. 11).

Desta feita, sáo as formas de exercício da participação no espaço público que devem desperta maior atenção. O caráter de descentralização que pressupóe a intervençâo dos sujeitos sociais como garantia da materialização dos princípios da gestáo escolar e educacional democrática exige uma postura de embate a esse modelo gerencial, fato que reclama o envolvimento das instâncias de participação, nâo apenas no interior de sua própria estrutura, mas, sobretudo, na relaçấo com as demais instâncias do sistema de ensino.

Faz-se importante mencionar que ao conceber a possibilidade da atuação dos sujeitos coletivos nos espaços públicos, aqui sendo particularizado o campo educacional, estamos, ao mesmo tempo, enfatizando a necessidade de se romper com a lógica de uma participação planejada e regulada pelo Estado. O modelo de administraçáo estatal que o governo Fernando Henrique Cardoso impôs pautava-se na difusão de um sentimento de democratização que impunha à escola um diálogo restrito a decidir sobre os mecanismos que melhor atendessem ao imposto pelo sistema, sendo essas iniciativas asseveradas como autonomia local de decidir conforme sua realidade particular.

Portanto, o enfoque na relação da escola com as demais instâncias do sistema precisa levar em conta a consideraçáo do caráter propositivo que a unidade de ensino, por intermédio de seu colegiado, deve assumir em relação às decisóes a serem implementadas no sistema. Isso significa a necessidade de se refletir sobre as condiçóes em que os consensos sāo construídos entre as instâncias, assim como em que medida os dissensos que emanam dos diversos grupos sociais interferem no direcionamento das decisóes, como forma de se fazer valer os princípios da gestáo educacional democrática. 


\section{IMPACTOS DA REDEMOCRATIZAÇÃO NO CONTEXTO EDUCACIONAL}

O grande anseio por um novo paradigma de gestáo educacional, pautado na participação e consubstanciado pelo exercício da autonomia dos segmentos que atuam nas instâncias do sistema de ensino é decorrente da mobilização popular, já apresentada neste trabalho. Tal postura política surtiu efeito, sobretudo na influência exercida junto ao Congresso Nacional, resultando na promulgação da Constituiçáo Federal de 1988, especialmente no que se refere ao Capítulo III - Da Educaçáo, da Cultura e do Desporto, preconizando, em seu art. 206, que o ensino será ministrado com base em sete princípios. Entre eles, destacamos o princípio da gestáo democrática do ensino público na forma da lei (Inciso VI).

A relevância desse dispositivo legal, instituído na lei mais importante do país, reside no fato de que sua repercussão passou a ser notável em outras leis mais específicas e de espectro territorial mais restrito. Contudo, ainda referindo-se ao contexto da legislação de âmbito nacional, enfatizaremos, a seguir, a grande contribuição da Lei de Diretrizes e Bases da Educaçáo Nacional - LDB/96², mesmo já reconhecendo que o longo trâmite (1988-1996), durante os oito anos de reformulaçóes, supressóes e acréscimos na Câmara dos Deputados e no Senado Federal, tenha modificado drasticamente o projeto original defendido pelos educadores e todos os que se engajaram desde a primeira hora na defesa da educação pública.

Assim, a LDB/96 preceitua, em seu art. 3º, o também disposto no art. $206 \mathrm{da}$ Constituição Federal, com o destaque para a incumbência dos sistemas municipais de ensino, dispondo como um dos princípios e fins da educaçáo nacional - a gestão democrática do ensino público na forma da lei e da legislação dos sistemas de ensino. Como também, em seu artigo 14, a LDB/96 assiná-la para os meios em que a democratização da gestão educacional deve pautar-se, afirmando que os sistemas de ensino definirão as normas da gestáo democrática do ensino público na educaçáo básica, de acordo com suas peculiaridades e conforme os seguintes princípios:

I - Participação dos profissionais da educação na elaboração do Projeto Pedagógico da escola;

${ }^{2}$ Um exemplo de lei específica, cuja publicação expressa bem os movimentos da década de 1980, é a Lei de Diretrizes e Bases da Educação Nacional n 9.394/96. Ferreira $(2003,78)$ ressalta que "A LDB embora pesem os seus limites recondicionantes, é a expressão das lutas efetivadas entre as diversas forças sociais e, dessa forma, apresenta-se como um balizador para as políticas educacionais no país e, consequentemente, para as políticas de democratização da escola e da gestáo escolar". 
II - Participaçáo das comunidades escolar e local em conselhos escolares ou equivalentes.

Consideremos o construto disposto no novo marco legal como um fundamento do processo de democratizaçáo do país para a construçáo de um novo paradigma de gestão educacional, no qual a perspectiva de fortalecimento da autonomia da escola constitui o principal viés que deve orientar as relaçóes no interior do sistema de ensino. A importância do novo marco legal reside, sobretudo, no reconhecimento de que um regime democrático precisa amparar-se em condiçóes objetivas claras e válidas para todos os partícipes das relaçôes que serão estabelecidas.

É concebível que aceitemos a consideração de que o movimento em defesa da democratizaçâo da gestão educacional esteve sempre atento à urgência das mudanças das práticas exercidas pelos dirigentes escolares, sobretudo no que trata da exigência de uma postura do gestor para além de suas responsabilidades administrativas, ressaltando, sobremaneira, o pedagógico como atribuição essencial de sua função. A esse respeito, observa-se que não apenas a postura de atuação do gestor, mas também, as relaçôes interpessoais entre os sujeitos envolvidos com o ato educativo; a discussão sobre os métodos e estratégias de ensino; a reformulaçáo da estrutura curricular da educação nacional são alguns dos elementos reconhecidos como inerentes à instituição do regime democrático no Brasil, quando nos referimos especialmente aos trabalhos desenvolvidos no âmbito educacional.

Segundo Gadotti (1997), a gestão democrática deve ser impregnada na atmosfera que se respira na escola, na circulação das informaçóes, na divisão dos trabalhos, no estabelecimento do calendário, na distribuiçáo e organização das aulas, na formação de grupos de trabalho e na capacitação dos recursos humanos. Nesse sentido, os princípios da autonomia e da participaçáo na escola, táo enfáticos quando nos referimos à temática da gestáo democrática, não significa apenas elencar as condiçôes objetivas para a vivência do regime democrático num documento escrito, é necessário sentir a presença em todos os movimentos da escola.

O que Gadotti (1997) chama a atençâo diz respeito à reflexão sobre o que fazemos com as regras do jogo e, sobretudo, quem participa da formulação e reformulaçáo dessas regras. O que estamos afirmando é que a contribuição de Bobbio (1986), com sua concepção procedimental de democracia, é válida para o debate que estamos desenvolvendo. Todavia, deve-se ter como horizonte náo apenas conhecer e saber aplicar as normas que balizam o regime democrático. Estamos igualmente interessados em discutir as possibilidades da participaçáo ampliada dos sujeitos que necessariamente devem estar também habilitados a corroborar com o processo 
contínuo de revisão das regras do jogo democrático. Pretende-se, na realidade, uma discussáo mais ampla na qual o fluxo do poder imposto autoritariamente na direção descendente (que desce, decrescente) precisa ser posto em situaçáo de embate, em que se procura pôr em evidência a possibilidade crescente do exercício do poder no espaço público em direção ascendente (que sobe, se eleva).

Entendemos que o processo de democratização da gestáo educacional não pode se pautar por outra premissa senáo a do trabalho enfático na defesa da direção ascendente do exercício do poder, fato que exige a garantia de condiçōes para que os indivíduos possam sentir-se responsáveis pela proposição, não apenas pela execução de tarefas; pela prática do dissenso como expressão de compromisso com a definiçáo das normas e medidas em prol do coletivo, não apenas assevera consensos sem que as discussóes tenham acontecido.

A esse respeito, consideramos pertinente a assertiva de Bobbio (1986, p. 55), como uma expressão sintética pode-se dizer que, se hoje se pode falar de processo de redemocratizaçăo, ele consiste náo tanto, como erroneamente muitas vezes se diz na passagem da democracia representativa para a democracia direta quanto na passagem da democracia política em sentido estrito para a democracia social, ou melhor, consiste na extensáo do poder ascendente, que até agora havia ocupado quase exclusivamente o campo da grande sociedade política (e das pequenas, minúsculas, em geral politicamente irrelevantes associaçóes voluntárias), para o campo da sociedade civil nas suas várias articulaçôes institucionais.

$\mathrm{Na}$ verdade, o processo de reconquista da democracia exigia uma extensão para além dos limites do Estado, ou seja, a sociedade, especialmente as suas instituiçóes sociais, precisava também se redemocratizar. Como considera Bobbio (1986, p. 55),

uma coisa é a democratizaçấo do Estado (ocorrida com a instituiçấo dos parlamentos), outra coisa é a democratização da sociedade, donde se conclui que pode muito bem existir um Estado democrático numa sociedade em que a maior parte das suas instituiçóes - da família à escola, da empresa à gestâo dos serviços públicos - náo são governadas democraticamente.

Pode-se afirmar que no embate pela democratizaçâo da sociedade há sujeitos que procuram exprimir seus dissensos como defesa de seu direito à contestação, mas também pela consciência de que, na democracia, o consenso unânime é, com poucas exceçóes, expressão de manipulação. $\mathrm{O}$ questionamento - o que fazemos dos dissentâneos? - parece inevitável quando nos propomos a discutir o processo de de- 
mocratização da sociedade, sobretudo no que se refere à relevância da participação popular na administraçáo pública, partindo-se do pressuposto de que a intervençáo no espaço público está, em larga dimensáo, atrelada ao "ato de coragem" dos sujeitos sociais de externar seus dissensos.

Conceber os dissensos como condição inerente à prática dialogal nos espaços públicos constitui o grande desafio a ser enfrentado pelo sujeito envolvido com a democratização durante todo o processo de elaboração e implementação das políticas educacionais. Nessa lógica, os dissentâneos expressam o que é mais natural nas relaçōes sociais, ou seja, que os sujeitos da açáo coletiva veem os fatos por óticas diferentes e, assim, manifestam suas opinióes com base em convicçóes que coincidem ou náo com as defendidas pelos outros.

Portanto, conceber efetivamente a participação de sujeitos populares no espaço público pressupóe chamá-los a um diálogo à luz dos princípios democráticos e estar disposto a considerar os pontos de vista desses diferentes sujeitos num mesmo plano de relevância. Faz-se, então, pertinente a consideraçáo de Bobbio (1986, p. 62) quando elabora questionamentos sobre a validade dos consensos unânimes, ao indagar:

que valor tem o consenso onde o dissenso é proibido? Onde não existe ação entre consenso e dissenso, onde o consenso é obrigatório e até mesmo premiado, e onde o dissenso não apenas é proibido, mas é também punido?; é ainda consenso ou é pura e simples aceitação passiva do comando do mais forte?; se o consenso não é livre que diferença existe entre o consenso e a obediência ao superior tal qual prescrita por todos os ordenamentos hierárquicos?

Essas indagaçôes do autor nos remetem à reflexão sobre a qualidade da participação nos conselhos de educação, assim como quais as suas influências nas decisôes adotadas pelo sistema de ensino. A preocupaçáo com a forma em que o consenso é construído entre as instâncias de participação da gestão educacional diz respeito não apenas à análise da garantia dos espaços de discussão, mas, sobretudo, ao conteúdo que compóe a pauta dos debates. Isso significa dizer que a proibição da manifestação de dissensos pode ser também decorrente da ausência de discussão de determinados temas, ou ainda quando as questóes discutidas não corroboram com a definição das políticas, ficando táo-somente no plano da escolha de mecanismos de execução de tarefas na escola.

Segundo Paro (2003, p. 50),

o que se observa é que o discurso da participação, quer entre políticos e administradores da cúpula do sistema do ensino, quer entre o pessoal escolar e a direção, 
está muito marcado por uma concepção de participação fortemente atrelada ao momento da execução. Esses indivíduos, pertencentes aos diferentes segmentos do sistema educacional, querem a participação da comunidade em tudo, mas, quando se trata de participar nas decisões, não aceitam.

Pode-se dizer que a discussão do processo de democratização deve incluir a reafirmação de que participar do processo de decisão na gestão escolar e educacional requer a qualidade de intervenção dos sujeitos em nível de negociação das normas e medidas a serem implementadas, contemplando, necessariamente, o direito ao questionamento sobre o quê, o como e o para quê ao discutirem coletivamente as propostas. Diante disso, o diálogo constitui o mecanismo mais plausível, mas o ato de dialogar pressupóe a condiçáo de negociação com os que pensam diferente de nós, e isso náo significa impor aos outros nossas "convicçóes da verdade". É preciso, na verdade, oportunizar ambientes de discussóes saudáveis, em que cada partícipe perceba sua importância a partir do tratamento respeitoso durante a decisáo compartilhada.

\section{O NOVO DESENHO DA GESTÃO EDUCACIONAL NO ÂMBITO DO PODER LOCAL}

A Constituição Federal de 1988, ao prescrever no Art. 22, inciso XXIV, que compete à Uniáo legislar sobre diretrizes e bases da educaçáo nacional; que compete à União, aos Estados e ao Distrito Federal legislar sobre educaçáo, cultura, ensino e desporto (Art. 24, inciso IX); e que é competência comum da União, dos Estados, do Distrito Federal e dos Municípios proporcionar os meios de acesso à cultura, à educação e à ciência (Art. 23, inciso V), firma a exigência de que cada ente federativo, ao instituir suas normas próprias sobre educação, atente para a observância dos princípios que regem a organização da educação nacional; portanto, requer a necessária articulação para que o princípio da autonomia que resguarda a atuaçáo das três esferas de poder náo prescinda da unidade nacional.

Diante desse cenário, o interesse dos pesquisadores em investigar os novos desafios da gestão da educação no âmbito do poder local tem sido demonstrado pela diversidade de aspectos estudados, abordando, essencialmente, o papel do conselho escolar no processo de democratização da gestão educacional (Andrade, 2007); a política de financiamento da educação e seus efeitos no pacto federativo (Abraháo, 2005; Castro 2007; Pinto, 2007); Federalismo e relaçóes intergovernamentais no Brasil (Carneiro, 2002; Arretche, 2002); a gestão política dos sistemas públicos no 
contexto da reforma do Estado e da municipalização do ensino no Brasil (Souza; Faria, 2004; Arelaro, 2007; Capanema, 2004; Bittar; Oliveira, 2004); Dilemas da reforma municipal no Brasil (Santos Junior, 2001); O desafio da ampliação do espaço de participação na gestão da educação pública (Teixeira, 2004; Lerclerc, 2002) e as relaçóes entre sistemas de ensino e planos de educação no âmbito dos municípios (Saviani, 1999), entre outros.

A leitura dos trabalhos que tratam das temáticas acima permite inferir o reconhecimento do processo de fortalecimento do poder local, sobretudo no que diz respeito às novas atribuiçóes das municipalidades no campo da gestáo da educaçáo, fato que tem sido retratado em conjunto com o debate sobre a descentralizaçâo administrativa dos serviços essenciais do Estado, instigando importantes mudanças no âmbito do financiamento e da consecução dos mecanismos de proposiçáa, implementação e acompanhamento das políticas educacionais.

Os novos dispositivos constitucionais (Art. 211 da CF de 1988 e Art. $8^{\circ}$ da LDB/96) preconizam, expressamente, o Regime de Colaboraçáo entre os sistemas de ensino, o que se infere a possibilidade de decisóes compartilhadas entre os entes federados, concebendo-os como iguais e autônomos entre si. O município pode decidir entre as três possibilidades previstas na LDB-96, quais sejam: a) instituir o próprio sistema de ensino; b) integrar-se ao sistema estadual de ensino; c) compor com o Estado, no âmbito de seu território, um sistema único de educação básica. Nesse sentido, compreendemos, assim como Sarmento (2005), que a criaçáo dos sistemas municipais de ensino pode ser entendida como a opção do município em assumir a autonomia em relação à política educacional, tendo como pressuposto a participaçáo de setores das comunidades nos Conselhos Municipais de Educaçáo.

Não obstante, os estudos sobre a gestáo dos sistemas de ensino indicam que o rumo dado à apropriação das possibilidades de descentralizaçáo das políticas educacionais no âmbito do poder local ainda se confronta com obstáculos de caráter histórico, político e cultural (Capanema, 2004; Otranto, 2006; Krawczyk, 1999). Isso significa que há dimensões a serem analisadas no contexto político-social em que cada sistema municipal de ensino está inserido.

É oportuno realçar que o papel que se reclama do sistema de ensino quanto à sua incumbência de interferir na realidade social, numa perspectiva de operar meios que promovam sua transformação, se insere no conjunto do movimento de redemocratizaçáo do País, por meio do qual o ideal da participação social no espaço público é apresentado e defendido como principal bandeira. Com efeito, é com base nessa conjuntura que a atenção à educação municipal, em conformidade com a noção de 
sistema que estamos aqui nos referindo, começa a ser concebida paulatinamente. $\mathrm{O}$ processo nessa direção é viabilização por intermédio do movimento de criação dos Conselhos Municipais de Educação, mesmo antes de uma legislação específica, uma vez que esta matéria apenas é contemplada no novo marco legal dos anos 1980/90.

É a partir do advento dessa nova legislação que passa a vigorar na educação brasileira que dedicamos maior atençáo neste estudo. Assim, cabe uma menção inicial ao fato de que o surgimento do Sistema Municipal de Ensino (SME) aparece numa conjuntura em que o Município ganha força e expressão autônoma do ponto de vista geopolítico. Portanto o SME, apesar de ter sido engendrado em conjunto com a criação dos demais espaços de participaçáo, conforme já nos referimos, é somente no momento em que o Município ascende ao nível de ente federado autônomo que o ideário de sistema ganha possibilidade de concretude no âmbito municipal ${ }^{3}$.

A afirmação política dos municípios brasileiros - enquanto entes federados legitimamente revestidos de poder para legislar sobre a educação básica - é mais bem explicitada pela Lei de Diretrizes e Bases da Educação no 9.394/96, que estabelece caracterização para os níveis em que os sistemas serão organizados (Federal, Estadual e Municipal), além de reconhecer o papel dos sistemas de ensino como mecanismo para assegurar às unidades escolares públicas de educaçáo básica, em cada âmbito administrativo, progressivos graus de autonomia pedagógica e administrativa e de gestáo financeira (Art. 15). Quanto ao que se compreende tecnicamente por Sistema Municipal de Ensino, a LDB/96 (Art. 18), especifica que sua abrangência inclui: a) as instituiçóes do ensino fundamental, médio e de educaçáo infantil mantidas pelo poder público municipal; b) as instituições de educaçáo infantil, criadas e mantidas pela iniciativa privada; e c) os órgãos municipais de educação.

Não obstante, o espectro político que o SME engloba contempla dimensóes concernentes aos mecanismos de operação dos objetivos que justificam o caráter de intencionalidade e de açáo articulada com que se vincula o funcionamento sistêmico. Sari e Kirst (1997, p. 12) explicam essa dimensão do SME, destacando que "o Estado, ao requerer que o Município comprove a aplicação mínima de $25 \%$ de sua receita de impostos, a existência e funcionamento de Plano de Carreira do Magistério e de Conselho Municipal de Educação, além de Plano Municipal de

${ }^{3}$ Lesbaupin (2000, p. 7), baseando-se em estudos sobre os novos desafios do poder local na atual conjuntura de globalizaçáo, reconhece as iniciativas exitosas em algumas municipalidades quanto ao potencial de democratização do poder público, ao colocar em evidência que "alguns governos municipais têm conseguido reverter em seus municípios o processo de exclusáo promovendo a inclusão de setores sociais desfavorecidos". 
Educaçáo, pressupóe uma organizaçáo do ensino estruturada e com grau elevado de autonomia".

Esta assertiva salienta o plano das atribuiçóes dos SMEs, fato que transcende a estrita descrição da lei quando trata dos componentes de cada jurisdição administrativa em que os sistemas de ensino estáo vinculados. O que se busca pôr em relevo, quanto se trata da dimensão político-funcional de cada sistema, é a especificidade com que cada um dos entes federados mobiliza suas forças, mediante instâncias legitimamente estabelecidas, com o propósito de atender as demandas por políticas educacionais nos diversos âmbitos de prioridade. A perspectiva de açáo articulada dos SMEs tem sua definiçáo explicitada a partir da consecução dos planos educacionais e da criaçáo de mecanismos que desenvolvam o acompanhamento de sua implantação no contorno da educação municipal. Percebe-se que o atendimento, no que se refere aos progressivos graus de autonomia com que os sistemas de ensino estão incumbidos de garantir às escolas, está, consideravelmente, subordinado ao nível de organização de cada sistema, tomando como referência a legitimidade de suas instâncias quanto ao exercício do planejamento, direção, comunicação e controle social de suas açōes.

\section{DESAFIOS E POSSIBILIDADES DA PARTICIPAÇÃO NA GESTÃO DO SME}

A criação do SME constitui um indicativo de descentralização na gestão da educaçáo, inspirada no ideário da decisão compartilhada no espaço público em que o acordo passa a ser concebido como resultante da mediaçáo de conflitos; por conseguinte, a exteriorização dos dissensos é reconhecida enquanto premissa inexorável no processo de proposição, execução e avaliação das políticas educacionais.

Faz-se importante realçar que a constituição de um sistema de ensino pressupóe, portanto, a pluralidade de concepçóes ideológicas que implícita ou explicitamente guardam interesses pela disputa do poder. Nesse sentido, é pertinente a posição de Gomes (2002), quando chama a atenção para a lógica de funcionamento sistêmico, referindo-se à educaçáo superior com o argumento de que os elementos e instituições que constituem um sistema são "postos a operar conjuntamente a partir dos marcos legais, das políticas em cursos estabelecidas pelo atual grupo no poder $\mathrm{e}$ também em funçáo dos interesses institucionais e dos grupos que mobilizam interesses particulares e/ou projetos sociais" (p. 277-278).

Pode-se considerar que a opçáo do Município por instituir seu sistema próprio de ensino, quando associada à possibilidade do poder local assumir sua autonomia em relação à política educacional, pressupóe uma rearticulação entre as instâncias 
sociais que compartilham dos processos educativos no Município (secretaria de educação, sindicatos, conselhos escolares, associaçáo de moradores, universidades, entre outras), na perspectiva de que os mecanismos de interlocução da participação social, nessa esfera de poder federado, possam constituir-se legitimamente como espaço de mediação discursiva, em face da mobilização de interesses particulares e/ou projetos sociais, tanto pelos representantes institucionais quanto pelos diferentes grupos que disputam o exercício do poder no campo educacional.

A possibilidade da participaçáo social em nível de compartilhamento das decisóes políticas assumidas pelo sistema de ensino perpassa desafios que, num primeiro momento, reclama a capacidade de articulação dos organismos da sociedade civil no que diz respeito ao fortalecimento de sua representação nas instâncias de participação democrática, em seguida, faz-se necessário investir em formação dos representantes, na expectativa de que os anseios do conjunto de seus pares sejam competentemente defendidos nos momentos de disputa, em que se constatam interesses concorrentes entre os grupos que pleiteiam fazer prevalecer seus projetos, utilizando-se, inclusive, de rituais de gestáo colegiada.

Em razão desse entendimento, a composição dos conselhos de educação tradicionalmente levou a efeito, como critérios de escolha dos conselheiros, a disposiçáo política dos sujeitos em mediar a comunicação, mas, especialmente, a capacidade intelectual desses indivíduos ("notório saber") para o cumprimento das funções que lhes são atribuídas. Tais prerrogativas são apontadas como mecanismo de viabilização de maior participação do executivo no conselho e, sobretudo, na escolha dos conselheiros que deveriam ser aclamados por intermédio de sufrágio de seus pares. Este último pressuposto parece ter sido contemplado no advento do novo marco legal (CF, 1988; LDB, 1996), ao revestir os conselhos de uma nova feição, referendada pelo ideário de articulaçáo da participação cidadã na gestão dos sistemas de ensino. É apropriado considerar que,

sob a égide desse novo papel, o critério da representatividade social passou a ser considerado como relevante para a indicaçăo de conselheiros. No entanto, a complexidade das decisóes dos conselhos requer conhecimentos relativos à formulação de políticas educacionais, de normas e de processos pedagógicos. A combinação de critérios, do saber e da representatividade social, na escolha dos conselheiros, passou a ser requerida para a composição dos conselhos. No critério do saber, náo pode ser desconsiderada a dimensão da pluralidade dos saberes, tanto o acadêmico quanto o das vivências pessoais e sociais. (Brasil, 2006, p. 46) 
Observa-se que os desafios e as possibilidades da participação no interior dos sistemas de ensino estão imbricados com o movimento de materialização da funçáo de articulação dos conselhos de educação, no que concerne à mediaçáo da voz da sociedade aos encaminhar suas aspirações aos setores do Estado governista. Há de se convir que a combinação dos critérios saber e representatividade social na escolha dos conselheiros constitui prerrogativa pertinente à investidura na funçâo. Não obstante, faz-se importante destacar que o "saber" dos sujeitos sociais engajados nos colegiados deve ser concebido num processo de construção contínua, considerandose, neste caso, os saberes da experiência que guardam coerência e relevância com o campo educacional, além do que os saberes pedagógicos, muitas vezes requeridos como base na discussão de questóes técnicas da educação, devem ser contemplados no processo sistemático de formação dos conselheiros.

A ênfase atribuída no marco legal, a respeito do critério de representatividade em que os sujeitos são aclamados em função de sua inserção social, reclama, por sua vez, ressonância pragmática na atuação dos conselhos de educação, tendo por perspectiva o incremento da agenda sistemática de trabalho, contemplando, de forma mais intensa, atribuiçóes, como: a) sensibilização do poder público quanto à responsabilidade de garantir equidade no processo de melhoria da qualidade da educação por meio do tratamento diferenciado das disparidades que se apresentam no cenário educacional; e b) realização de alianças e cooperação interinstitucional com as instâncias de participação, legitimamente instituídas no sistema de ensino, com o propósito de efetivar mecanismos de descentralizaçáo do poder decisório, avançando-se, por conseguinte, no fortalecimento da interlocução entre a sociedade e o poder público, especialmente na dinâmica que envolve a formulaçáo, implantaçáo, acompanhamento e avaliação da política educacional.

Este desenho de açáo dos conselhos de educação que atuam em nível de sistema de ensino pressupõe a transcendência do exercício de atribuiçóes como emissão de alvará de funcionamento, reconhecimento e/ou credenciamento de instituiçóes educacionais, assim como a realizaçáo de sindicâncias, solicitaçáo de esclarecimentos dos responsáveis e formalização de denúncias aos órgãos competentes ao constatar irregularidades. Tais serviços correspondem às funçóes consultiva, normativa e fiscalizadora que certamente constituem parte substantiva de suas prerrogativas de funcionamento; não obstante, devem ser operadas em sinergia com as funçóes propositiva e mobilizadora.

Entendemos que o exercício da função propositiva pelos conselhos de educação exige, necessariamente, a conjugação de critérios como conhecimento técnico e representatividade social, por pressupormos sua inferência como recurso potencializa- 
dor de maior responsabilidade e compromisso coletivo com o atendimento das demandas por políticas de educação, incluindo-se, ainda, maior possibilidade de uma sistemática de avaliaçâo institucional com vistas ao encaminhamento de medidas para a promoçáo de melhoria do fluxo e do rendimento escolar. Quanto à função mobilizadora, o que está em causa é o interesse de instigar o conjunto dos segmentos sociais no acompanhamento dos serviços educacionais, presumindo-se, para tanto, a reuniāo de esforços, tanto por parte do executivo quanto por parte da sociedade civil organizada. Desta feita, há de se convir que a mobilização perpasse o empreendimento de articulaçóes entre os pares que possuem assento nos conselho. Nesse aspecto, o que se pretende não é apenas a postura altiva dos sujeitos em exigir maior agilidade dos órgãos gestores quanto à apresentação de respostas às requisições sociais para o campo educacional, mas, sobretudo, maior mobilização dos próprios sujeitos que exercem a representação, em face do atual quadro em que se constata considerável dissociação entre a voz do representante e os anseios dos representados.

Faz-se importante considerar que o conjunto das funçóes apresentadas é também identificado como expectativa de intervenção dos conselhos de educação vinculados aos processos educativos que se desenvolvem no âmbito do poder local. Tal consideraçáo realça, com efeito, o momento de reafirmação dos municípios quanto à materialização de seu status de ente federado, ao fazer uso de sua competência para normatizar a política educacional que vigorará em seu âmbito de prioridade. Esta alternativa de açáo que passa a ser reconhecida das municipalidades exige o cumprimento de importantes passos, tendo em vista a implantaçáo de seu sistema de ensino. Conforme nos esclarece Saviani (1999, p.132-133), as principais providências sáo: a) verificar a eventual necessidade de ajustes na Lei Orgânica do Município; b) elaborar um projeto de lei do sistema de ensino do município a ser aprovado pela Câmara Municipal; c) organização ou, se já existe, reorganizaçáo do Conselho Municipal de Educação, de acordo com o disposto na Lei do Sistema Municipal de Ensino; e d) dar ciência dessas iniciativas à Secretaria Estadual de Educação e ao Conselho Estadual de Educação.

O conjunto das alteraçóes sugeridas por Saviani (1999) aponta para uma nova concepçáo de gestão da educação no âmbito municipal em que se faz necessário o ajuste da legislaçáo, sobretudo no que concerne ao redirecionamento do papel a ser exercido pelas instâncias de participação legitimamente instituídas neste ente de poder federado, tendo por perspectiva a construção de mecanismos de mediação dos interesses de vários sujeitos sociais no processo de definição das políticas educacionais. A elaboraçáo da Lei do Sistema Municipal de Ensino é decorrente 
de um processo legislativo que primeiramente atua na adequaçāo da Lei Orgânica do Município. Uma vez instituída sob a guarda de dispositivos legais específicos, a educaçáo municipal passa a ser regida à luz de prerrogativas estabelecidas no espaço social de lutas que são empreendidas em função dos diferentes projetos que buscam sua afirmaçáo no campo educacional.

Percebe-se que a expectativa de funcionamento do sistema de ensino pressupóe o exercício de disputa de poder entre seus membros, fato que reclama a organização ou, se já existe, reorganização do Conselho Municipal de Educação. É pertinente considerar a imprescindibilidade dessa instância para o exercício da autonomia no interior do sistema de ensino, uma vez que sua principal finalidade é a mediação da participaçáo social na gestáo educacional, constituindo-se, substancialmente, uma alternativa ao autoritarismo que se mantém arraigado fortemente nas práticas gestionárias assumidas pelo gestor, mesmo aquele que ocupa o cargo e que foi escolhido por meio de mecanismos democráticos. É justamente por considerarmos essa conjuntura que entendemos, em concordância com Cury (2004, p. 59), que "uma cultura adequada à nova intencionalidade, que permitiu o avanço legal de muitos Conselhos - produto de pressão nos tempos das Constituintes Federal e Estaduais e da elaboração das Leis Orgânicas -, ainda está para ser construída, inclusive mediante a presença ativa nos órgãos colegiados dos sistemas". Nessa construçáo, exige-se uma postura de aceitação de pluralidade de concepçóes de modo a corroborar com a fixação de prioridades e metas em conjunto com as representaçóes dos vários segmentos sociais, permitindo, por conseguinte, que o executivo identifique e supra, com maior precisão e eficácia, as demandas do setor educacional.

A questáo que merece ser considerada primariamente, quando se pensa num investimento em benefício da construçáo de uma cultura adequada à nova intencionalidade correlata ao movimento de planejamento e implementação das políticas públicas, vincula-se intrinsecamente à qualidade da participaçáo nas esferas de poder deliberativo para estabelecer prioridades em conformidade com as reivindicaçóes da populaçáo. Nesse sentido, um sistema municipal de ensino, concebido à luz de inspiraçóes democráticas, precisa respaldar-se em mecanismos de participaçáo que compreenda a diversidade de segmentos envolvidos com a educação do município. Trata-se de compreender a necessidade de fortalecimento da relaçáo com instâncias de representação social como os conselhos escolares, as associaçóes de bairro, assim como o movimento estudantil e suas formas de organização no interior das unidades de ensino. 


\section{CONSIDERAÇÕES FINAIS}

Pode-se afirmar que o impacto do novo marco legal brasileiro no contexto da gestáo educacional revela alteraçóes substantivas, tanto no que diz respeito ao movimento de construçáo das condiçóes objetivas para a gestão democrática da escola quanto à abertura para a intervenção dos sujeitos envolvidos com os processos educativos no sentido de democratizar as regras que organizam o jogo democrático entre as instâncias que compóem os sistemas de ensino.

É justo considerar que a gestão democrática, assim como foi forjada nos anos 1980 , é um construto que somente poderá confirmar sua semântica progressista se for resultado de acordos estabelecidos a partir da pluralidade de pontos de vista dos sujeitos que participam do debate no espaço público. Diante disso, deve-se considerar como processo de democratização as relaçóes que comportam espaços para o dissenso. Assim, é oportuno asseverar que quanto maior for a participação de sujeitos na discussão no espaço público, menor será a possibilidade de ostentaçáo da concepção imutável do poder. Quanto mais abrangentes forem os espaços de manifestaçáo da palavra, menor será a possibilidade de consenso unânime em torno do projeto defendido pelas instâncias superiores que representam o Estado. Quanto maior for a intensidade de diálogo, menor será a aceitação da ordem social tal qual historicamente vem se reproduzindo.

Cabe ressaltar a imprescindibilidade do bom funcionamento dos conselhos municipais de educaçáo enquanto fator indubitável para operacionalidade do novo paradigma gestionário da educação municipal. Desta feita, alguns aspectos, como a periodicidade das reunióes, a garantia de condiçóes favoráveis ao desempenho das funçóes dos conselheiros, assim como das instalaçóes onde os conselhos funcionam, sẩo essenciais ao caráter sistêmico de gestão. Em tese, a definiçáo de intervalos regulares entre as reunióes do conselho municipal (frequência quinzenal ou mensal) pressupóe maior efetividade da participação social de seus membros na gestão do sistema de ensino, partindo-se do entendimento de que o ritmo sistemático das discussóes é condição indubitável para a construção comunicativa do acordo quanto à intencionalidade da ação educativa em nível do sistema. Desta feita, a irregularidade em relação às ediçóes de reunióes do conselho indica uma sistemática de ação com maior probabilidade de desenvolvimento de açōes episódicas, quando náo de caráter meramente emergencial.

Uma das consequências destacáveis da reconstrução do marco legal para a gestáo da educação municipal diz respeito à legitimidade das instâncias de participaçáo quanto ao exercício do planejamento, direção, comunicação e controle social das polí- 
ticas educacionais no âmbito do Sistema Municipal de Ensino. Tais atribuiçôes vinculam-se, intrinsecamente, à elaboração do Plano Municipal de Educaçáo, devendo ser concebido à luz dos princípios da gestáo democrática em que se pressupóe a açáo colegiada como elemento fundamental do processo de descentralização do poder decisório sobre quais açóes governamentais serão operadas no campo educacional em consonância com as intençóes acordadas entre o executivo e os representantes dos diversos grupos sociais.

Sobre esta nova incumbência, faz-se importante a observância de alguns passos básicos que consideramos pertinentes nesta discussão. Em primeiro momento, destaca-se a necessidade de se proceder a uma diagnose das principais demandas educacionais. Nesta etapa, a atenção é centrada naquilo que preconiza o marco legal quanto aos níveis de ensino sob prioridade do poder local para o setor da educação (ensino fundamental e educação infantil), avançando-se, progressivamente, na busca pelo atendimento de modalidades consideradas relevante no espectro da educação básica, como a educação especial, a alfabetização e educaçáo de jovens e adultos e o ensino médio. Ressalta-se que a oferta dos diferentes níveis e modalidades de ensino tem como premissa o regime de colaboração entre os entes federados, considerando-se as especificidades de cada unidade da federação.

Para o segundo passo, enfatiza-se a exigência de que as normas de procedimentos que nortearão a confecção do plano sejam explicitadas, no sentido de que as opçóes elencadas, assim como as prioridades acatadas pelo coletivo estejam resguardadas sob justificativas plausíveis. Esse elemento coaduna-se com o terceiro passo, para o qual destacamos a exigibilidade da definiçáo das metas a serem contempladas num cronograma que correlacione opçóes e prioridades com etapas a serem operadas ao longo do período de vigência do plano. Trata-se de levar a efeito um conjunto de açóes pautadas em intençóes objetivas quanto às exigências diagnosticadas na primeira fase do plano.

Na sequência, têm-se a preocupaçáo com a caracterização dos recursos correspondentes às especificidades de cada prioridade assumida. Este é mais um elemento que deve ser discutido numa perspectiva de ação compartilhada, principalmente entre o Município e o Estado, sobretudo quando se refere ao provimento da infraestrutura necessária às atividades inerentes à escolarizaçáo, como: a) adequação do número de escolas e de salas de aula ao quantitativo de alunos, de acordo com as exigências de cada nível e modalidade da educação; b) disponibilização de material didático em conformidade com as necessidades de cada etapa da educaçáa; e c) contratação de profissionais da educação e garantia de formação continuada, respei- 
tando-se a área e/ou setor de atuação (professor, pessoal de apoio como secretários de escola, serviço geral, merendeiras etc.).

Há também a colocação de que se faz necessário a elaboração e difusão do orçamento financeiro contendo as receitas e despesas em conformidade com o desenho do plano, informação que corresponde à indicação das fontes disponíveis e adicionais que iráo assegurar a viabilidade das metas e açóes planejadas. Pode-se afirmar que o processo que envolve a elaboração do Plano Municipal de Educação (desde a diagnose até a apresentaçáo do cronograma e orçamento financeiro) reforça tanto a exigência de intencionalidade e coerência no que diz respeito à correlação entre prioridades e capacidade de resposta às demandas educacionais, quanto a necessidade de colaboração entre os entes federativos no que concerne à gestão do sistema de ensino, uma vez que se faz necessário cumprir as prerrogativas dispostas na organização da educaçáo nacional, buscando, sobretudo, a garantia do acesso e permanência dos alunos em todos os níveis e modalidades da educação básica. É, sobretudo, por esta razão que o caráter sistêmico na gestão educacional pressupóe não somente a mera divisão de responsabilidades, mas também o acompanhamento do cumprimento das atividades de competência de cada esfera de poder, por meio da participaçáo dos sujeitos sociais que compartilham dos processos educativos.

\section{REFERÊNCIAS BIBLIOGRÁFICAS}

ABRAHÃO, J. Financiamento e gasto público da educação básica no Brasil e comparações com alguns países da OCDE e América Latina. Educação \& Sociedade, Campinas, v. 26, n. 92, 2005. Disponível em: <http:// www.scielo.br/pdf/es/v26n92/v26n92a07. pdf >. Acesso em: 30 out. 2008.

ANDRADE, E. F. O Papel dos conselhos escolares na democratização da gestão educacional no municipio do Recife. 2007. Dissertação (Mestrado) - Universidade Federal de Pernambuco, Recife.

ARELARO, L. R. G. Formulação e implementação das políticas públicas em educação e as parcerias público-privadas: impasse democrático ou mistificação política? Educação \& Sociedade, Campinas, v. 28, n. 100, 2007. Disponivel em: <http://www.scielo.br/ pdf/es/v28n100/a1328100.pdf>. Acesso em:
30 out. 2008.

ARRETCHE, M. Relações federativas nas políticas sociais. Educação \& Sociedade, Campinas, v. 23, n. 80, 2002. Disponível em: <http://www.scielo.br/pdf/es/v23n80/12922. pdf >. Acesso em: 30 out. 2008.

AZEVEDO, J. M. L. Implicações da nova lógica de ação do Estado para a educação municipal. Educação \& Sociedade, Campinas, v. 23, n. 80 , 2002. Disponível em: <http://www.scielo.br/pdf/ es/v23n80/12923.pdf >. Acesso em: 30 out. 2008.

BITTAR,M.; OLIVEIRA, J.F.(Org.). Gestãoe políticas da educação. Rio de Janeiro: DP\&A, 2004.

BOBBIO, N. O Futuro da democracia: uma defesa das regras do jogo. 5.ed. Rio de Janeiro: Paz e Terra, 1986.

BRASIL. Constituição da República Federativa do Brasil. Brasília, 1988. 
BRASIL. Ministério de Educação e Cultura. Lein ${ }^{\circ}$ 9394/96. Lei de Diretrizes e Bases da Educação Nacional. Brasília, 1996.

SEB. Perfil dos Conselhos Municipais de Educação. Brasília, 2006.

CAPANEMA, C. F. Gênese das mudanças nas políticas públicas e na gestão da educação básica. In: BITTAR, M.; OLIVEIRA, J. F. (Org.). Gestão e políticas da educação. Rio de Janeiro: DP\&A, 2004.

CARNEIRO, E. Regime de colaboração sem subordinação ou hierarquia. Cadernos de Educação Municipal, Brasília, n. 2, 2002.

CASASSUS, J. Tarefas da educação. Campinas: Autores Associados, 1995.

CASTRO, J. A. Financiamento e gasto público na educação básica no Brasil: 1995-2005. Educação \& Sociedade, Campinas, v. 28, n. 100, 2007. Disponível em: <http://www. scielo.br/pdf/es/v28n100/a1128100.pdf >. Acesso em: 30 out. 2008.

COUTINHO, C. N. Democracia e socialismo. São Paulo: Cortez, 1992.

. A Democracia na batalha das ideias e nas lutas políticas do Brasil de hoje. In: FÁVERO, O.; SEMERARO, G. (Org.). Democracia e construção do público no pensamento educacional brasileiro. Rio de Janeiro: Vozes, 2002.

CURY, C. R. J. Os Conselhos de Educação e a gestão dos sistemas. In: FERREIRA, N. S. C.; AGUIAR, M. A. S. Gestão da educação: impasses, perspectivas e compromissos. 4.ed. São Paulo: Cortez, 2004.

FERREIRA, N. S. C. (Org.). Gestão democrática da educação: atuais tendências, novos desafios. São Paulo: Cortez, 2003.

GADOTTI, M. Projeto político pedagógico da escola: fundamentos para a sua realização. In: GADOTTI, M.; ROMÃO, J. E. (Org.). Autonomia da escola: princípios e propostas. 2. ed. São Paulo: Cortez, 1997.

GOMES, A. M. Política de avaliação da educação superior: avaliação e controle. Educação \& Sociedade, Campinas, v. 23, n. 80, 2002. Disponível em: <http://www.scielo.br/pdf/es/ v23n80/12933.pdf >. Acesso em: 30 out. 2008.

KRAWCZYK, N. A Gestão escolar: um campo minado... análise das propostas de 11 municípios brasileiros. Educação \& Sociedade, Campinas, v. 20, n. 67, 1999. Disponível em: <http://www.scielo.br/pdf/es/v20n67/ v20n67a04.pdf >. Acesso em: 30 out. 2008.

LECLERC, G. Sistema único de ensino: o desafio da construção e da ampliação do espaço público de direitos na escola pública de Mato Grosso. Educação \& Sociedade, Campinas, n. 78, abr. 2002. Disponível em: <http://www.scielo. br/pdf/es/v23n78/a12v2378.pdf>. Acesso em: 30 out. 2008.

LESBAUPIN, I. O Desmonte da nação em dados. Petrópolis, RJ: Vozes, 2000.

LESBAUPIN, I.; MINEIRO, A. O Desmonte da nação em dados. 2. ed. Petrópolis: Vozes, 2002.

LIMA, C. L. Políticas educativas e educação popular: a cidadania democrática e os imperativos do mercado competitivo. In: CONFERÊNCIA DE ENCERRAMENTO DO SEMINÁRIO EDUCAÇÃO, TEORIA CRÍTICA E PEDAGOGIA: 20 ANOS DA PEDAGOGIA DA REVOLUÇÃO, 2004, Pernambuco. Anais... Pernambuco: UFPE, 2004.

OTRANTO, C. R. Desafios da educação municipal. Educação \& Sociedade, Campinas, v. 27, n. 94, 2006. Disponível em: <http:// www.scielo.br/pdf/es/v27n94/a17v27n94.pdf>. Acesso em: 30 out. 2008.

PARO, V. H. Gestão democrática da escola pública. São Paulo: Ática, 2003.

PINTO, José Marcelino de Rezende. A Política recente de fundos para o financiamento da educação e seus efeitos no pacto federativo. Educação \& Sociedade, Campinas, v. 28, n. 100, 2007. Disponivel em: <http://www.scielo.br/ pdf/es/v28n100/a1228100.pdf>. Acesso em: 30 out. 2008.

SADER, E. Quando novos personagens entraram 
em cena: experiências, falas e lutas dos trabalhadores da grande São Paulo, 1970-1980. Rio de Janeiro: Paz e Terra, 1988.

SANTOS JUNIOR, O. A. Democracia e governo local: dilemas da reforma municipal no Brasil. Rio de Janeiro: Revan, 2001.

SARI, M. T.; KIRST, T. O Município e a educação. Porto Alegre: Famurs, 1997.

SARMENTO, D. C. Criação dos sistemas municipais de ensino. Educação \& Sociedade, Campinas, v. 26, n. 93, 2005. Disponível em: <http://www.scielo.br/pdf/es/v26n93/27285. pdf>. Acesso em: 30 out. 2008.

SAVIANI, D. Sistemas de ensino e planos de educação: o âmbito dos municípios. Educação \& Sociedade, Campinas, v. 20, n. 69,
1999. Disponível em: <http://www.scielo.br/ pdf/es/v20n69/a06v2069.pdf>. Acesso em: 30 out. 2008.

SOUZA, D. B.; FARIA, L. C. M. Reforma do estado, descentralização e municipalização do ensino no Brasil: a gestão política dos sistemas públicos de ensino pós-LDB 9.394/96. Ensaio: avaliação e políticas públicas em educação. Rio de Janeiro, v. 12, n. 45, 2004. Disponível em: <http://www.scielo.br/pdf/ensaio/v12n45/ v12n45a02.pdf >. Acesso em: 30 out. 2008.

TEIXEIRA, L. H. G. Conselhos municipais de educação: autonomia e democratização do ensino. Cadernos de Pesquisa, v. 34, n. 123, set./ dez. 2004. Disponível em: <http://www.scielo. $\mathrm{br} / \mathrm{pdf} / \mathrm{cp} / \mathrm{v} 34 \mathrm{n} 123 / \mathrm{a} 09 \mathrm{v} 34123 . \mathrm{pdf}>$. Acesso em: 30 out. 2008. 